\title{
Chinese and Indian FDI in Hungary and the role of Eastern Opening policy
}

\author{
Katalin Völgyi ${ }^{1,2}$ (1) Eszter Lukács ${ }^{2}$
}

Received: 7 June 2019 /Revised: 30 June 2020 / Accepted: 23 November 2020/

Published online: 18 January 2021

(C) The Author(s) 2021

\begin{abstract}
The aim of this paper is to assess the main features of Chinese and Indian investments in Hungary and the role of the Hungarian Government's Eastern Opening policy in the attraction of investments from these two Asian giants. This paper covers the sectoral distribution, modes of market entry, and motivations of Chinese and Indian foreign direct investments. The automotive sector is the most attractive sector for investors from both countries. ICT manufacturing (electronics) and services, and the renewable energy sector are also very attractive for Chinese companies. The same is true for IT/ BPO services and the chemical sector in the case of Indian companies. Chinese and Indian companies enter the Hungarian economy mainly through green-field investments or acquisitions. Market-seeking and strategic asset-seeking motives are dominant in the case of investors from both countries. This paper also puts a special emphasis on studying the impacts of Hungary's Eastern Opening policy (launched in 2012) on Chinese and Indian investments. The findings show that the Eastern Opening policy has had a significant impact on the investment decision (location choice) of new Chinese and Indian investors and further expansion of investments by Chinese and Indian companies located in Hungary due to four factors, namely high-ranking political meetings, strategic cooperation agreements, cash grants from the Hungarian Government and supportive services of HIPA.
\end{abstract}

Keywords China $\cdot$ India $\cdot$ Foreign direct investments $\cdot$ Hungary $\cdot$ Eastern opening policy

Katalin Völgyi

volgyi.katalin@krtk.hu

1 ELKH Centre for Economic and Regional Studies, Institute of World Economics, Tóth Kálmán utca 4, Budapest 1097, Hungary

2 Széchenyi István University, Egyetem tér 1, Győr 9026, Hungary 


\section{Introduction}

Rapidly developing Asia in the global economy provides several topics for academic research. The growing share of developing economies, especially from Asia, in the global outward foreign direct investments of transnational corporations is one which is worth dealing with. 'Traditionally, the vast majority of transnational corporations (TNCs) that operate across borders have originated from developed countries such as the United States, Japan and members of the European Union' (Dunning et al. 2008, p. 158). In the past, developing countries mainly functioned as host economies for foreign direct investments of these TNCs. Although the greater proportion of global FDIs have still originated from developed country TNCs in recent decades, TNCs of some developing and transition economies have been playing an increasingly important role in outward FDI (UNCTAD 2006, p. 245). In this regard, we should highlight the significance of BRICS (Brazil, Russia, India, China and South Africa) among developing and transition countries. In 2017, BRICS countries accounted for $8.5 \%$ of global outward FDI stock and 36\% of outward FDI stock from developing and transition economies. In flow terms, their share was $12.4 \%$ and $42.3 \%$, respectively. In this paper, we deal only with outward foreign direct investments of Asian members of BRICS, namely China and India with a host country focus on Hungary. This investigation is motivated by one of the main goals of Hungary's Eastern Opening policy, namely the attraction of more FDI from the East (Asia). We undertake a comparative analysis of foreign direct investments of Asia's two largest economies in a small CEE market which is not a priority destination country for them. The paper is structured as follows:The short 'Introduction' section is followed by a literature review. The 'Literature review' section focuses on the main publications which deal with Chinese and Indian investments in Europe, including Hungary. The next section provides a general overview of global FDI of Chinese and Indian TNCs. The 'Hungary's Eastern Opening policy' section presents the main goals and measures of the Eastern Opening policy. The 'Chinese and Indian foreign direct investments in Hungary' section describes the main features of Chinese and Indian foreign direct investments in Hungary with a special focus on the last decade and the role of the Eastern Opening policy. Finally, some conclusions are made at the end of the paper.

\section{Literature review}

In 2006, UNCTAD chose FDI from developing and transition economies as a special topic for its annual World Investment Report which signalled the rapid increase of outward FDI from these countries. This phenomenon has started to gain more and more attention from scholars. Regarding the topic of our study, it is worth making a brief overview of some of those publications which deal with Chinese and Indian foreign direct investments in Europe, Central and Eastern Europe and Hungary. For example, Hay and Milelli (2011, p. 153) analysed a dataset of Chinese and Indian investments in Europe from the early 1980s to 2007 and conducted face-to-face interviews in some European countries in 2007 to determine 'their distinct advantages, motives and strategies as well as the potential impacts on the EU'. According to their findings, 'an overcrowded and highly competitive market as well as strong government support 
are the main 'push' factors that drive Chinese and Indian companies to increasingly operate abroad. For the Chinese and Indian companies targeting the European area, market access is the primary motivation. This is often manifest in the setting up of sales offices and distribution centres, regional headquarters or technical centres to back up companies' exports and get closer to European customers or even to circumvent antidumping measures' Hay and Milelli 2011, p. 154). Created assets such as management capabilities, technological know-how, marketing expertise and brand awareness 'rank second in the motivations of Chinese and Indian companies for coming to Europe. For them, "acquisitions are the main route to tap intangible assets, but organic expansion is also used to set up development centres and design institutes within/or close to technological clusters in recipient countries"' (Hay and Milelli 2011, p. 155). Regarding the mode of market entry, company dataset of Hay and Milelli (2011, p. 157) shows that 'Chinese have so far privileged de novo investments whereas Indian companies have relied more on acquisitions. However, a convergence trend has emerged since 2007, with Chinese firms clinching to more acquisitions while their Indian counterparts engage in more green-field investments'. Hay (2016) and Milelli (2016) also conducted two separate pieces of research regarding Chinese and Indian investments in Europe which assessed the changes in these investments during and after the global financial and economic crisis. Both studies present a detailed analysis on the ownership, modes of entry and motives of investing companies and the distribution of investments among European host countries and sectors. In the case of China, we can highlight that the destination countries of Chinese investments have become more diversified since the global crisis, but large western European economies such as France, Germany and the UK have remained the main target countries. The sectoral distribution of Chinese investments has also shown some changes. New target sectors such as utilities, energy and infrastructure have appeared beside the equipment, transportation/logistics, automotive, textile-fashion, telecommunication and finance sectors. Within the equipment sector, new activities have emerged in the medical equipment, precision and new energy equipment sector. As for modes of entry, the global financial and economic crisis (European sovereign debt crisis) induced a rise of Chinese acquisitions in Europe and the quest for strategic assets was, by far, the first motive of Chinese investors in 2009-2010. From the perspective of the geographical limitation of our study, it is worth mentioning the findings of Hay (2016, p.117-118) on CEE countries: 'Chinese investments in eastern Europe have increased and diversified since the crisis. Apart from the investments in the transport activities (generally made before 2009), they principally concern equipment, the automobile and telecom sectors, home appliances, and chemistry. Manufacturing activities are prominent. That is explained by attractive labour costs, less strict regulations than in western Europe, and the opportunity to use the label "made in Europe", which is important to European customers and to weaken protectionist resentments'. In the case of India, Milelli (2016, p. 158) finds that during the global financial and economic crisis and subsequent European sovereign debt crisis, in contrary to their Chinese counterparts, Indian companies invested less in Europe. As for modes of entry, 'M\&A activity of Indian companies picked up during 2006-2008 (pre-crisis period). But green-field investment and extensions were the preferred modes of entry of Indian investors for the years 2010-2012. This indicates that the low valuation of local companies with even fire-sale prices, as a consequence of the European debt crisis, was not seen as a genuine 
opportunity by Indian firms. They had a preference for extensions over M\&As in order to consolidate sales bases, development centres or plants' (Milelli 2016, pp. 161-162). As for the sectoral distribution, Milelli (2016, p. 164) identifies three clusters of Indian investments: IT services in general, pharmaceuticals and related products and engineered goods and metals. In addition, equipment and automotive combined sectors surpassed pharmacy and took the second rank in the list of sectoral distribution of Indian investments in Europe in the early 2010s. According to further findings of Milelli (2016, p. 161), similar to their Chinese counterparts, Indian companies prefer to invest in large western European countries. However, CEE countries 'are emerging as an alternate destination for manufacturing or professional services in a "near-shoring approach" (close to the market)'.

Chinese and Indian companies' growing presence in the CEE region including Hungary has also inspired some region- or country-case studies. Chinese investments in Hungary are mostly investigated in a broader geographical context (CEE) and often researched alongside political and other economic (trade, infrastructure development) relations. Zuokui (2013), Matura (2017), Zhang (2018), Szunomár et al. (2018), Lukács and Völgyi (2018a), Matura (2019) and Szunomár et al. (2020) analyse Chinese investments in Hungary under China-CEE relations or $17+1$ cooperation (in the framework of the Belt and Road Initiative (BRI)). In addition, there are some publications (Matura 2018; Lukács and Völgyi 2018b) which have a narrow focus on bilateral relations between China and Hungary. The aforementioned publications provide - to various extents - an insight into the trends, activities, motivations and modes of market entry of Chinese companies in the whole CEE region and/or Hungary. In the case of India, there is less academic literature available on the country's investments in Hungary. Lukács and Völgyi (2017) and Gerőcs (2018) investigate Indian investments in Hungary from a CEE perspective. Besides presenting the different characteristics of Indian investments (sectoral distribution, modes of market entry, motivations), these publications also indicate a potential role of the Hungarian government policy in Indian companies' investment decisions. The so-called Eastern Opening policy of the Hungarian Government also appears in the publications related to China-Hungary relations, but not as a main object for research.

To complement the aforementioned literature, we provide in this study a more detailed and up-to-date analysis of the characteristics of Chinese and Indian investments in Hungary. In addition, we assess the role of the Hungarian Government's Eastern Opening policy in Chinese and Indian investments. Government policy is an important push (home country) as well as a pull (host country) factor for Chinese and Indian companies (UNCTAD 2006, p. 157). In this study, we deal with the latter one.

\section{Chinese and Indian foreign direct investments on a global scale}

\section{Size of FDI outflows}

The expansion of developing country transnational corporations (and their foreign direct investments) was first predicted in the late 1970s. In his early assessment on developing country TNCs, Wells $(1983$, p. 3 ) concluded that 'the fact that so many have appeared in such a short time suggests that the overall numbers are likely to be considerably more 
impressive in the next few years'. Foreign direct investments from developing countries have taken off since the 1990s. Emerging Asian markets have contributed to this prevailing trend significantly. In 2014, the share of developing countries in the total FDI outflows reached 38\%. Developing Asia was the biggest source of global FDI, eclipsing the performance of North America and Europe. Among Asian developing countries, China has an outstanding role. Until 1999, China's outward direct investment policy was widely restricted. Between 1982 and 1991, annual average FDI outflows from China amounted to only 537 million US dollars. Although from 1992 to 1999 annual average FDI outflows increased to 2.7 billion US dollars, they remained considerably withheld by governmental restrictions. Following its accession to the World Trade Organization in 2001, China started to relax its outward direct investment regulations gradually. It launched the so-called going out (or going global) strategy as one of the key strategies in the Tenth Five-Year Plan (20012005) as a result of which Chinese FDI outflows took off (Wang and Gao 2018, p. 619) and reached a record level of 196.1 billion US dollars in 2016. Since 2012, China has been among the top three home countries of FDI, generally ranked in second or third place. In terms of annual FDI outflows, China can compete with the top traditional investors such as Japan and Western European countries. In the case of India, 'though the sprouting overseas investment was noticed in the early 1960s, most of the foreign affiliates set up by Indian firms during the ensuing two decades were small- or medium-scale ventures and annual total outflows remained small in the range of 3 to 5 million US dollars' (Athukorala and Veeramani 2016, p. 1). FDI outflows from India began to increase rapidly-following liberalization reforms - in the mid-1990s. 'In particular, there has been a surge in outflows since about 2005 following significant dismantling of foreign exchange restrictions on capital transfers for acquisition of foreign ventures by Indian firms during the period 2000-2004' (Athukorala 2009, p. 150). Annual average FDI outflows from India reached 16.9 billion US dollars between 2006 and 2010. Due to the global financial and economic crisis, annual FDI outflows from India dropped and became volatile. In 2017, they reached 11.3 billion US dollars. Contrary to the recent volatility, India has been showing considerable catching-up to the top home economies of global FDI. In 2017, it was the 23rd largest home country of FDI in global terms. And among developing countries, it was the 10th largest home country of FDI, while China was the largest one. In the case of China, FDI outflows have already caught up with the level of FDI inflows. In contrast with China, India has remained a net receiver of FDI.

\section{Main investors}

In China, in spite of the recent decrease in their share, state-owned companies still account for more than half of total outward foreign direct investment stock (data of 2016). In parallel, private companies have started to play a significant role in Chinese FDI outflows (KPMG 2018, p. 72). In the case of India, the bulk of outward foreign direct investments originate from privately owned business groups or stand-alone companies. State-owned companies only have a modest role in FDI outflows. These only focus on investments in energy resources (Pradhan 2017, p. 62). Every year, UNCTAD compiles the list of the top 100 non-financial TNCs from developing and transition economies ranked by foreign assets. ${ }^{1}$ The list is dominated by Chinese

\footnotetext{
${ }^{1}$ See the full list at: https://unctad.org/en/Pages/DIAE/World\%20Investment\%20Report/Annex-Tables.aspx
} 
transnational corporations: large state-owned companies in mining and metal (e.g. China National Offshore Oil Corporation), chemical (e.g. China National Chemical Corporation), transport and storage (e.g. China COSCO Shipping Corporation) and construction sector (e.g. China State Construction Engineering Corporation) as well as in electronics (China Electronics Corporation), telecommunication (e.g. China Mobile Limited), utilities (e.g. China Three Gorges Corporation) and food and beverages sector (e.g. Cofco Corporation), etc. And we can also find some private companies in the list such as HNA Group, Fosun International Limited, Legends Holdings CorporationLenovo Group, Tencent Holdings, Dalian Wanda Group and Huawei Technologies. Indian transnational companies in the list such as Tata Motors (Tata Sons), Tata Steel (Tata Sons), Hidalco Industries (Aditya Birla Group) and Bharti Airtel Limited (Bharti Enterprises) are mainly part of private business groups except the Oil and Natural Gas Corporation which is a state-owned company in the mining sector and Infosys Limited which is a private stand-alone IT company.

\section{Geographical/sectoral distribution and motives}

By the end of 2016, China's outward FDI stock was concentrated in Asia (67\%), followed by Latin America (15.3\%), Europe (6.4\%), North America (5.6\%), Africa (2.9\%) and Oceania (2.8\%) (Wang and Gao 2018, p. 626). The three top destination countries, Hong Kong (57.5\%), Cayman Islands (7.7\%) and British Virgin Islands (6.5\%), have had a relatively high share $(71.7 \%)$ in China's total outward FDI which can be explained by offshore and round-tripping activities. This means that Chinese FDI outflows to these countries are redirected to a third country or channelled back to China. But in recent decades, a new trend has evolved, namely the growing share of developed countries in Chinese outward FDI stock, rising from 7.4\% in 2009 to $14.1 \%$ in 2016 (Wang and Gao 2018, p. 626). The sectoral distribution of Chinese outward FDI also shows some changes. The initial dominance of the energy and mining sector has started to fade and sectors such as high technology manufacturing and services have become more attractive for Chinese companies. These changes also reflect China's industrial upgrading and economic transformation from an export, manufacturing and investment-driven growth model to a consumption-, innovation- and service sector-driven one. By the end of 2016, 85\% of China's total outward FDI stock was distributed among leasing and business services ${ }^{2}(34.9 \%)$, finance $(13.1 \%)$, retail and wholesale trade $(12.5 \%)$, mining $(11.2 \%)$, manufacturing $(8 \%)$, information transmission, software and IT services (4.8\%) (Li 2018, p. 24). 'Chinese FDI outflows are driven by multiple objectives such as seeking market expansion, resources and assets, brands, technology and know-how. Acquiring resources and energies used to be the priority, but in recent years acquiring high-quality assets, and access to global marketing channels, advanced technologies, products and brands (in developed countries) have become predominant motives' (Meng et al. 2018, p. 13).

In the case of India, between 2000 and 2014, 56\% of cumulative FDI outflows were directed to developing regions: $51 \%$ to Asia, $36 \%$ to Africa, $12 \%$ to Latin America and the Caribbean. The main destination countries were Singapore, United Arab Emirates, British Virgin Islands and Mauritius. The share of developed regions in India's

\footnotetext{
$\overline{2}$ These investments are often redirected to another sector.
} 
cumulative FDI outflows was 42\%. Europe and North America received $75.4 \%$ and $19.5 \%$ respectively of India's cumulative FDI outflows to developed regions. The main target countries in developed regions were the USA, the UK, Switzerland, the Netherlands and Cyprus (Pradhan 2017, pp. 53-58). Similar to China, the geographical distribution of outward FDI from India should be interpreted with caution, because a part of Indian FDI outflows to countries such as Mauritius, Singapore, the British Virgin Islands, Cyprus, etc. may be redirected to other countries or channelled back to India (round-tripping). Sectoral distribution shows that primary sector was targeted by only $9.6 \%$ of cumulative FDI outflows from India between 2000 and 2014. The manufacturing and services sector was able to attract $39.3 \%$ and $48.2 \%$ of Indian FDI outflows. Indian foreign direct investments in the primary sector are mainly related to state-owned companies in the petroleum and natural gas sector (Chaudhry et al. 2018 , p. 19). The distribution of manufacturing FDI outflows from India have recently become more diversified from basic metals, chemicals, coke and refined petroleum products toward pharmaceuticals, motor vehicles, machinery and equipment which reflects the development of India's domestic industrial sector. India's economy, however, is dominated by the service sector, so the leading role of service companies in FDI outflows is not surprising. Indian companies primarily target communication services, IT and IT-enabled services, construction and the financial and insurance sector (Pradhan 2017, p. 51). Outward direct investments from India are driven by resource-seeking, market-seeking and strategic asset-seeking motives. Indian foreign direct investments in petroleum and the natural gas sector have been seeking to secure access to natural resources. Similar to China, 'current outward FDI of India is, to large extent, aimed at accessing strategic assets through M\&A. Strategic asset-seeking companies search for complementary assets abroad, or seek to circumvent entry barriers in marketing and distribution in developed countries by acquiring brands, distribution, and marketing systems. Moreover, some Indian companies have become so strong that they are capable of taking on market-seeking investment in developed countries, aimed, for example, at getting closer to customers (IT) and networks (pharmaceuticals and engineering), or at consolidating global oligopolistic expansion (steel and automotive)' (Hansen 2010, p. 29).

\section{Hungary's Eastern Opening policy}

The 2007-2009 global financial and economic crisis and the subsequent 2010-2011 European sovereign debt crisis, which resulted in a massive backdrop in European GDP and trade growth figures as well as that of inward FDI, motivated the Hungarian Government to launch the so-called Eastern Opening policy as an integral part of its new foreign economic policy strategy in 2012 to facilitate exports to as well as inward FDI flows (mainly) from Asian countries, among others, China and India and mitigate Hungary's massive commercial (concentration both in terms of country orientation and sectors) and FDI dependence on the EU-15 (Lukács and Völgyi 2017, p. 29). In addition, 'the foreign economic policy strategy took the beneficial geographical position of Hungary into account, by stating that the Eastern Opening is a natural way of utilising the country's good access point to the markets of Asian and post-Soviet states, which provides Hungary with the possibility to become a logistical and transportation 
hub between the European Union and Asia. Lastly, another motive behind a more Eastern-oriented foreign policy was the assumption that a proper representation of the Hungarian state interests on the world stage is only possible once the country is more visible and able to build on the possible support of relevant worldwide and regional players' (Dániel 2015, pp. 3-4).

The primary aim of the foreign economic policy strategy launched in 2012 is to contribute to the country's growth, employment and balance of payments goals with the six main objectives listed below:

1. The diversification of the geographical structure of exports

2. The diversification of the product structure of exports

3. FDI attraction

4. The support of exports and supplying activity of small and medium enterprises (SMEs)

5. Economic cooperation in the Carpathian Basin

6. Institutional development of economic diplomacy

In our paper, we focus on the goal of FDI attraction. The foreign economic policy strategy highlights the growing intention of BRIC countries to invest in Europe which means that BRIC countries can help Hungary to increase inward FDI and diversify its sources (NGM 2011, p. 30). Besides paying more attention to new 'big country' investors such as BRIC countries, more general aims were determined in the foreign economic policy strategy: developing the system of investment incentives, diverting investments to territories characterized by backwardness, increasing reinvestments, strengthening domestic suppliers, etc. (NGM 2011, p. 28). Since 2012, the Hungarian government has started to conclude strategic cooperation agreements with transnational companies located in Hungary to encourage them to reinvest their earnings in Hungary, develop R\&D activities, increase their participation in vocational training programmes and strengthen supplier relations with Hungarian SMEs (Éltetö and Völgyi 2013, p. 4). As of May 2020, 84 strategic cooperation declarations had been signed, among others, with Chinese companies such as Huawei Technologies Hungary, BorsodChem, Yanfeng Hungary, Bank of China, Wescast Hungary and SEGA Hungary and with Indian companies such as Tata Consultancy Services Hungary, CG Electric System Hungary and SMR Hungary. ${ }^{3}$ Several institutions like the network of attachés for foreign economic affairs, the Hungarian Investment Promotion Agency (HIPA) and Joint Economic Committees make efforts to increase foreign direct investments from China and India. Besides, there is a rapidly growing number of bilateral or regional high-ranking political meetings and business forums between Hungary and the two big Asian countries which also encourage inward FDI. On the regional level, we can highlight the role of China-CEE Summits $(17+1$ cooperation), China-CEE Economic and Trade Forums, China-CEE Investment and Trade Expos and India-Europe-29 Business Forums (formerly India-Central Europe Business Forums).

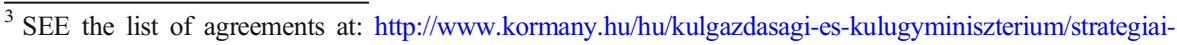
partnersegi-megallapodasok
} 


\section{Chinese and Indian foreign direct investments in Hungary}

\section{Chinese and Indian transnational corporations}

According to the data of the Hungarian National Bank (stock, ultimate investor), in 2017, 2.8\% and $2.1 \%$ of the total FDI stock in Hungary was from India and China. India and China are respectively the 10th and 12th largest source countries of FDI in Hungary. Of Asian countries, only Japan and South Korea have invested more than India or China in Hungary. Tables 1 and 2 include the most important Chinese and Indian investors in Hungary.

Both private and state-owned companies from China are present. The former are represented by Huawei Technologies, Midea Group, BYD, Yanfeng Automotive Interiors, Joyson Safety System, and Lenovo etc., the latter by Wanhua Chemical Group, ZTE, China COSCO Shipping Group, CRRC, Genertec and Bank of China, etc. Indian companies located in Hungary are privately owned. Some of them belong to large business groups: Tata Consultancy Services Hungary-Tata Sons, Dunakiliti Konzervüzem, Puszta Konzerv, Ganz Transelektro, Ganz Transverticum-Avantha Group, Birla Carbon Hungary-Aditya Birla, Group etc.

\section{Sectoral distribution}

Chinese and Indian companies in Hungary operate in the manufacturing or service industries. We can highlight the dominance of companies from both countries in the automotive industry. Besides this, the ICT manufacturing (electronics) and service sector is also very attractive for Chinese companies and Hungary has become an attractive host country for several Indian companies of IT/BPO services. Indian and Chinese automotive companies mainly producing different components (e.g. mirrors, tyres, tyre moulds, door panels, floor and overhead consoles, metal components) have been integrated into the automotive global supply chains which have a strong presence in the Hungarian economy. There are only two automotive companies, Electrobus Europe and BYD Electric Bus \& Truck Hungary, which do not produce automotive components, but electric buses. IT/BPO companies represent one of the internationally competitive sectors of India. A number of them such as Cognizant Technology Solution, Wipro, and Tata Consultancy Services have opened a subsidiary in Hungary. In the case of China, high-tech companies in the ICT manufacturing (electronics) and service sector such as Huawei Technologies, ZTE and Lenovo operate worldwide and are well known. We can also find some Chinese or Indian companies in the chemical, renewable energy, robotics, pharmaceutical, environmental, retail, food processing, logistics/transportation, banking sectors, etc.

\section{Modes of entry}

The entry pattern of Chinese and Indian companies shows green-field investments as well as acquisitions. In the case of Chinese companies, market entry is sometimes realized in the form of a joint venture. Indian companies have acquired several companies originally established by Hungarians such as Alkaloida (Sunpharma), Puszta Konzerv (Global Green/Crompton Greaves), Ganz Transelektro and Ganz 


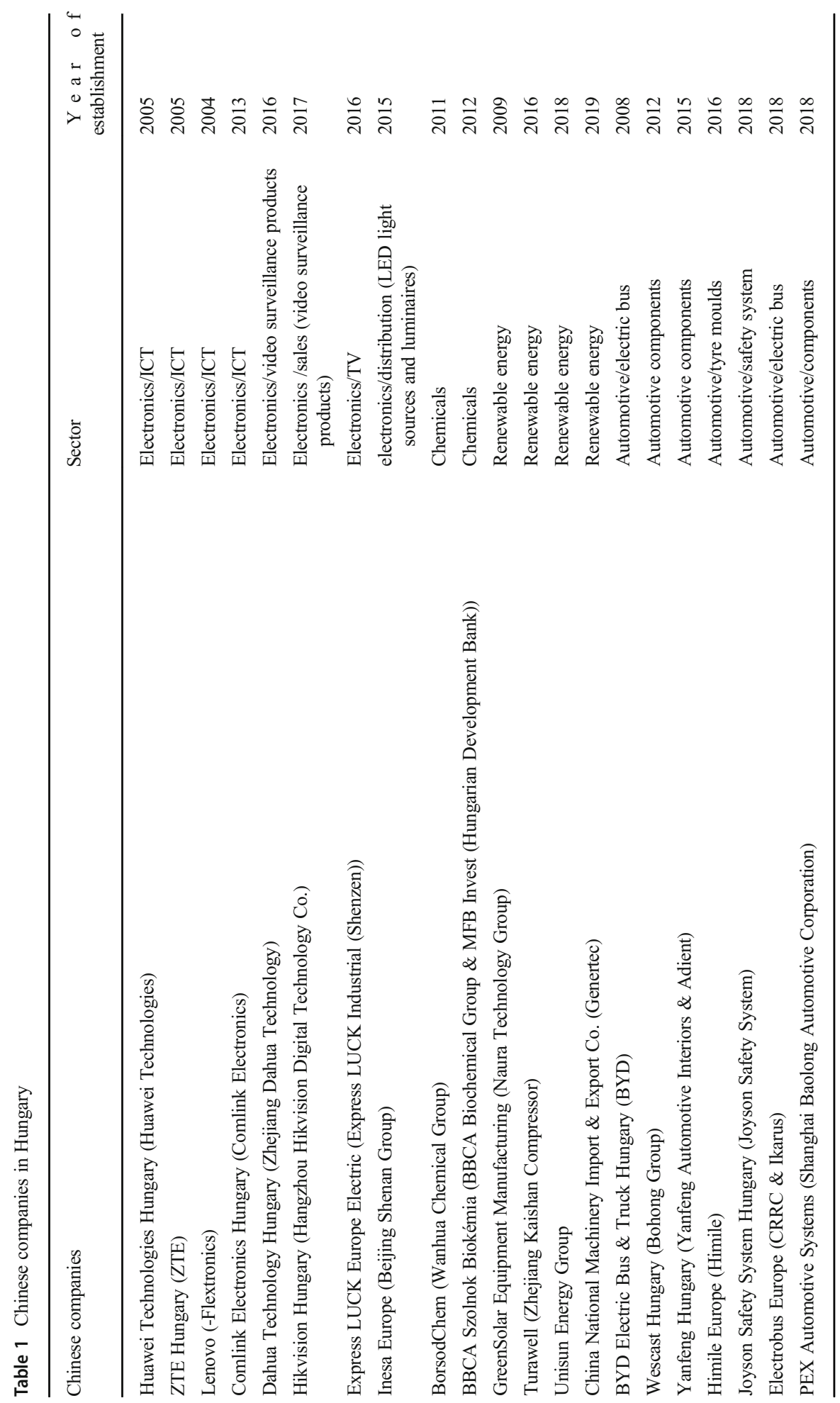




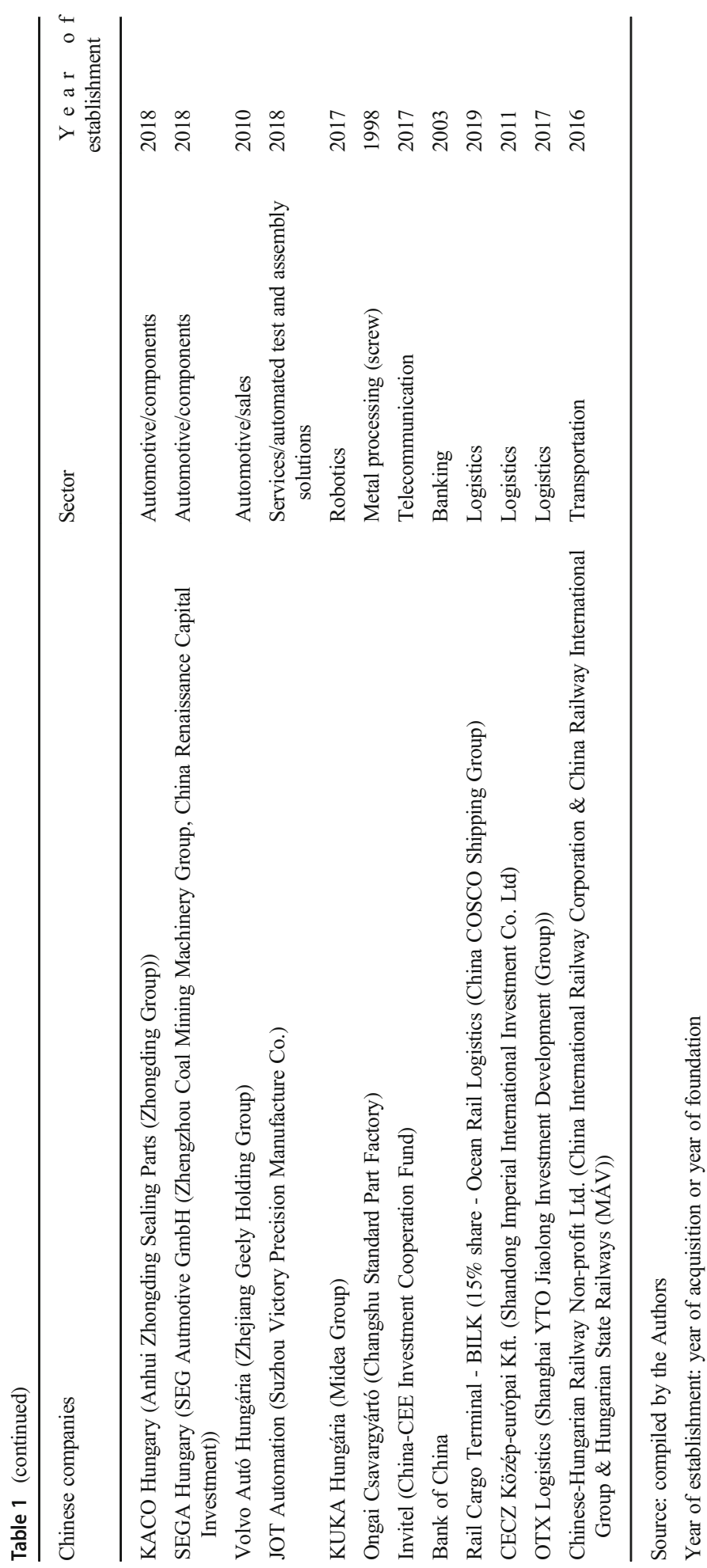


范

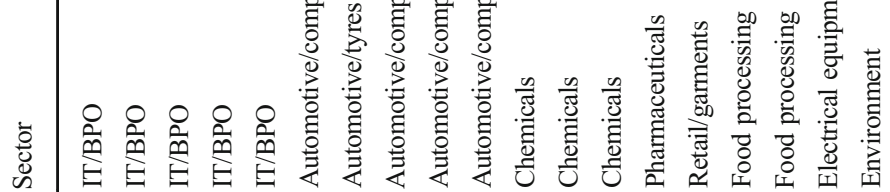
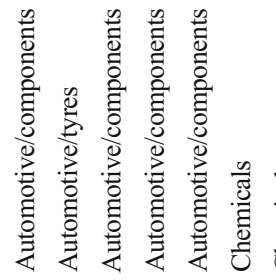

$\widehat{\widehat{\Xi}}$

总

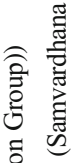

言㩊

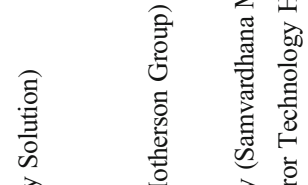

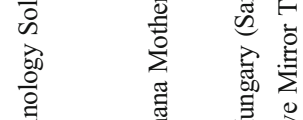

仓े

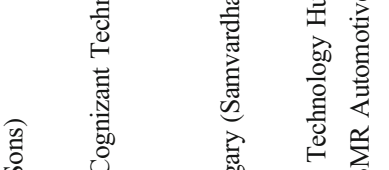

施 音

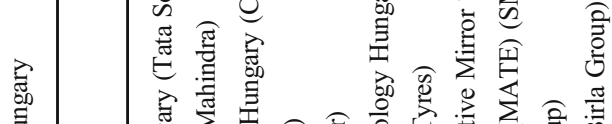

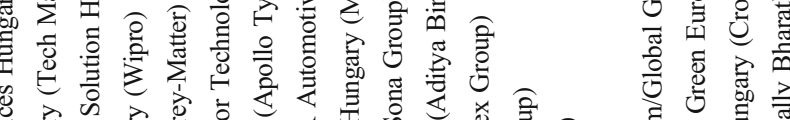

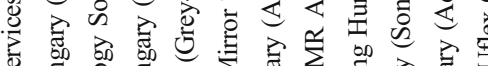

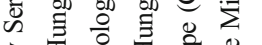

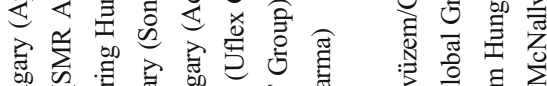

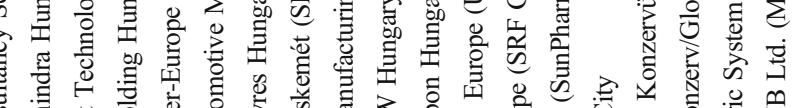

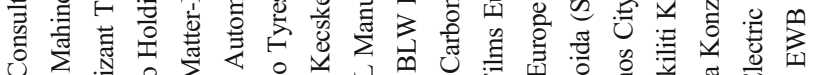

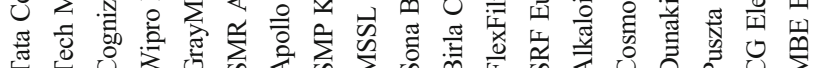

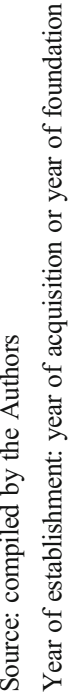


Transverticum (Crompton Greaves) and Ábrahám és Társa Kft. ${ }^{4}$ (SMR Hungary/ Samvardhana Motherson Group). And there are some examples for acquisitions in which Indian companies buy foreign companies which have subsidiaries in Hungary: Samvardhana Motherson Group-Visiocorp ${ }^{5}$ (SMR Hungary), Aditya Birla GroupColumbian Chemicals Company (Birla Carbon Hungary) and Crompton GreavesInterGarden (Dunakiliti Konzervüzem). All Indian investments in IT/BPO services have a green-field type. Over the last decade, there have been several green-field investments in the automotive sector. SMR Hungary opened a new factory in Mosonmagyaróvár in 2011 and an SMP factory in Kecskemét in 2017. In Túrkeve, it also launched a new SMR plant in 2018 and a new MATE plant in 2019. In addition, Sona Group and Apollo Tyres have carried out green-field investment projects in the automotive sector. In 2018, the building of a foil factory was announced by SRF Group as well as Uflex Group.

Chinese acquisitions show similarity to their Indian counterparts. Chinese companies have also bought foreign companies which have subsidiaries in Hungary: Bohong Group-Wescast (Wescast Hungary), Midea Group-KUKA (KUKA Hungária), Lenovo-IBM PC division, Joyson Safety System-Takata Corporation (Joyson Safety System Hungary), Shanghai Baolong Automotive Corporation-PEX Automotive (PEX Automotive Systems), Anhui Zhongding Sealing Parts-KACO (KACO Hungary), etc. Wanhua Industrial Group (now Wanhua Chemical Group), Beijing Sevenstar Group (now Naura Technology Group), Changshu Standard Part Factory and Zhejiang Kaishan Compressor have acquired companies with Hungarian roots (BorsodChem, Energosolar, Ongai Csavargyártó, Turawell (51\%)). We also have to mention the special case of Hungarian telecom firm Invitel, which was acquired in 2017 by the China-Central and Eastern Europe Investment Cooperation Fund (established under the Belt and Road Initiative). Unlike Indian companies, Chinese counterparts also establish joint ventures to enter the Hungarian market. For example, China International Railway Corporation and China Railway International Group (85\%) established a joint venture with Hungarian Railways (MÁV) $(15 \%)$ in 2015 to coordinate the upgrade of the Hungarian section of the Budapest-Belgrade railway line. Chinese BBCA Biochemical Group launched a joint venture with MFB Invest (subsidiary of the Hungarian Development Bank) in 2012. The building of their citric acid factory is still under progress in Szolnok. In 2015, Yangfeng Automotive Interiors and Johnson Controls (now Adient) established a joint venture, which became the owner of the former Hungarian subsidiary of Johnson Controls. In 2018, Electrobus Europe was set up as a joint venture by Ikarus, a Hungarian company with a long tradition in bus manufacturing, and Chinese CRRC, the world's largest rolling stock manufacturer. Beside acquisitions and JVs, we can find several green-field investments in different sectors as well: Huawei Technologies Hungary, ZTE Hungary, Comlink Electronics Hungary, Himile Europe, Bank of China, photovoltaic power stations of Unisun Energy Group and Genertec, etc.

\footnotetext{
${ }^{4}$ located in Túrkeve

${ }^{5}$ In 2009
} 


\section{Motivations}

Chinese investments in the service sector (e.g. logistics, transportation, banking) as well as in the manufacturing sector show market-seeking motivations. They are not only interested in the Hungarian market, but they often use Hungary as a (Central) European hub from where the European market can be supplied with Chinese products or services. For example, in 2009, Huawei Technologies located its European Supply Centre to Hungary which has been distributing Huawei products to Europe, Russia, North Africa and the Middle East. Chinese cable-maker Comlink Electronics followed its domestic purchaser Huawei Technologies and invested in the Hungarian market in 2013. The Flextronics plant in Sárvár supplies Europe, Africa and the Middle East with Lenovo products. In 2014, Bank of China launched its CEE headquarters in Budapest. Himile, which is the world's largest manufacturer of tyre moulds, opened its European service and manufacturing centre in Hungary in 2016. Express LUCK Industrial took over the plant of Samsung Electromechanics Industrial in Szigetszentmiklós in 2016 to open its first European TV factory. Beijing Shenan Group bought a $16,000 \mathrm{~m}^{2}$ real estate in Dunakeszi in 2015 which has been turned into a European distribution centre of its LED light sources and luminaries for industrial, commercial and household use. BYD opened its first European factory in Hungary in 2017 and supplies the European market with electric buses. Zhejiang Dahua Technology, which is a world-leading video-centric smart IoT solution and service provider, opened an assembling factory and its European supply centre in south-western Hungary in 2018. Chinese companies in the renewable energy sector operate photovoltaic or geothermal power stations to produce electricity for the Hungarian market. Chinese investments in the field of logistics and transportation (China International Railway Corporation and China Railway International Group, Shandong Imperial International Investment, China COSCO Shipping Group) contribute to the development of the China-Europe sea-land express passage under the BRI and support the rail transport of Chinese goods from the port of Piraeus to the centre of Europe.

Strategic asset-seeking investments from China have recently become dominant in the form of M\&A in technologically developed countries where Chinese companies are looking for advanced technology, brand and know how, etc. In Hungary, this type of M\&A was rare until the second half of the 2010s. In 2011, Wanhua Industrial Group (now Wanhua Chemical Group) acquired BorsodChem which has become the world's third largest isocyanate producer and increased its European presence through BorsodChem subsidiaries. By acquiring Energosolar in 2009, GreenSolar has obtained know how, a brand name and technical staff. In recent years, predominantly in the automotive industry, Chinese companies have bought several developed country TNCs which have a subsidiary in Hungary. From this point of view, acquisitions of Midea Group, Joyson Safety Sytem, Shanghai Baolong Automotive Corporation, Anhui Zhongding, Zhengzhou Coal Mining Machinery Group and China Renaissance Capital Investment can be classified as strategic asset-seeking investments.

We can primarily speak about market- and strategic asset-seeking investments in the case of Indian companies as well. Green-field investments in the IT/BPO sector are aimed at supplying the European or global market from a low-cost location like Hungary. Production from a relatively low-cost site and close to customers is also a significant motivation for Indian automotive component manufacturers. New green- 
field investments of packaging material producers such as Uflex Group and SRF Group are also aimed at producing closer to European customers. Similar to Chinese companies, Indian counterparts have obtained ownership of some Hungarian subsidiaries by acquiring developed country TNCs. Acquisitions of Samvardhana Motherson Group (Visiocorp) and Aditya Birla Group (Columbian Chemicals Company) can be classified as strategic asset-seeking investments. In a European acquisition wave, Hungarian Ganz Transelektro and Ganz Transverticum were bought by Crompton Greaves in 2006. CG was motivated to obtain leading manufacturing capacities extra high-voltage transformers, gas insulated switchgear and other related components (Leepsa and Mishra 2012, p. 239). The acquisition of Alkaloida by Indian SunPharma was motivated by the enlargement of the company's basket (similar to CG) of complex products in the formulation and active pharmaceutical ingredient businesses (Balcet and Bruschieri 2010, p. 134). In the food industry, Global Green Europe acquired Hungarian cannery Puszta Konzerv in 2008 to enter the Central Eastern European market, including the Baltic States and the Balkan region.

\section{Role of Eastern Opening policy}

In this part of our study, we assess the role of the Eastern Opening policy in the attraction of new Chinese and Indian investors and the further expansion of investments by Chinese and Indian companies located in Hungary. Here, we investigate the following four factors: high-ranking political meetings, strategic cooperation agreements, cash grants ${ }^{6}$ from the Hungarian Government and supportive services of HIPA. High-ranking political meetings between Hungary and China or India often serve as venues for concluding agreements or negotiating on investments with Chinese or Indian companies. Strategic cooperation agreements are mainly aimed at encouraging Chinese and Indian companies to extend their investments in Hungary, participate in the training of the Hungarian workforce and increase the number of their Hungarian suppliers and promote Hungary as an investment destination country for other foreign companies. These agreements establish strong and direct relations of Chinese and Indian companies with the administration of the Hungarian Government, especially HIPA. Cash grants based on a discretionary government decision are often provided to Chinese and Indian companies. For projects granted cash subsidies, 'HIPA undertakes all-inclusive project management and provides VIP treatment and comprehensive information about other subsidies available' (Bana 2015).

The Hungarian Government has signed 9 strategic cooperation agreements with Chinese and Indian companies (Huawei Technologies Hungary (2013), BorsodChem (2014), Yanfeng Hungary (2016), Bank of China (2017), Wescast Hungary (2017), SEGA Hungary (2020), Tata Consultancy Services Hungary (2013), CG Electric System Hungary (2013), SMR Hungary (2015)). Many of them have expanded their capacities/activities in Hungary in recent years.

- Huawei Technologies Hungary: A strategic cooperation agreement between Huawei Technologies Hungary and the Hungarian Government was signed in April 2013 when Hungarian Minister of Foreign Affairs and Trade Péter Szijjártó

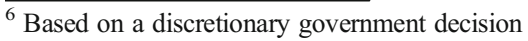


was on an official trip to Beijing. Under this agreement, Huawei Technologies Hungary boosted its headcount (to 2500) and expanded its warehouse space. Finally, it opened an enlarged logistics centre in Biatorbágy in 2013. It also brought its domestic supplier, cable-maker Comlink Electronics' investment to Hungary. In 2014, during an official visit of Hungarian Prime Minister Viktor Orbán to China, the Hungarian Investment and Trade Agency (predecessor of HIPA) and Huawei Technologies signed a memorandum of understanding on launching an innovation centre in Budapest and increasing production capacities of Huawei Technologies Hungary.

- BorsodChem: The Hungarian Government had already started to formulate the Eastern Opening policy when Hungarian Prime Minister Viktor Orbán visited Shanghai at the end of 2010 where he and his Chinese counterpart discussed, among others, the buyout of BorsodChem by Chinese Wanhua Industrial Group. The acquisition of BorsodChem was closed in 2011. A new TDI plant of BorsodChem was launched in 2011. This project was financially backed by Bank of China. In 2014, the Hungarian Government concluded a strategic cooperation agreement with BorsodChem in Beijing. To lure new further biotechnology and chemistry investors to Hungary, Wanhua invested EUR 200 million in the establishment of an industrial park (Sino-Hungarian BorsodChem Economic and Trade Cooperation Zone) next to BorsodChem plant. In the strategic cooperation agreement, the Hungarian Government pledged to give government supports (e.g. tax allowance) to companies investing in the industrial park. In 2017, BorsodChem announced that it would build a technologically advanced, environmentally friendly chlorine plant with the financial support of China Development Bank.

- Bank of China: In 2014, during his official visit to China, Hungarian Prime Minister Viktor Orbán met the President of Bank of China who announced that Bank of China would establish its CEE centre in Budapest and build a network of branch offices to finance Chinese companies' activities in Central and Eastern Europe. In 2017, the Hungarian Government and Bank of China concluded a strategic cooperation agreement. According to the agreement, Bank of China will finance Hungarian projects in line with the goals of the Belt and Road Initiative and encourage further Chinese investments in Hungary.

- Yanfeng Hungary: In 2016, Yanfeng Hungary announced that it would invest HUF 7.4 billion to expand its production capacity in Pápa. This project was qualified by the Hungarian Government as a major priority for the national economy. With the cooperation of HIPA, the Government provided funding (cash grant) to this project to the amount of HUF 1.85 billion (HIPA 2016). In the same year, the Hungarian Government concluded a strategic cooperation agreement with Yanfeng Hungary.

- Wescast Hungary: In May 2017, Hungarian Prime Minister Viktor Orbán accompanied by Minister of Foreign Affairs and Trade Péter Szijjártó travelled to China to attend the first Belt and Road Forum on International Cooperation. During this high-ranking political visit, the Hungarian Government signed a strategic cooperation agreement with Bohong Group in Chongqing where the Chinese company announced the launch of a new investment project (EUR 29 million) in Hungary.

- SEGA Hungary: The Hungarian Government and SEGA Hungary signed a strategic cooperation agreement in 2020. SEGA Hungary has started to build a new production hall where it will move to by the summer of 2021. When the 
cornerstone of the new production hall was laid, Commercial General Manager of SEGA, Uwe Mang, expressed his gratitude for the help and services provided by HIPA for this project (HIPA 2020).

- Tata Consultancy Services Hungary: TCS established its first Global Delivery Centre outside of India in Budapest in 2001. The Hungarian Government and TCS Hungary concluded a strategic cooperation agreement in 2013. In 2017, TCS Hungary expanded its capacities in Budapest and opened a new service centre with 500 new employees. HIPA provided its professional management consultancy services to TCS during the whole project (HIPA 2017).

- CG Electric System Hungary: In October 2013, Hungarian Prime Minister Viktor Orbán accompanied by a large business and official delegation visited India. In New Delhi, the Hungarian Government signed a strategic partnership agreement with CG Electric Systems Hungary.

- SMR Hungary: In 2015, the Hungarian Government and SMR Hungary signed a strategic cooperation agreement. They also agreed on a cash grant (HUF 7.7 billion) provided for the building of SMP factory in Kecskemét. This project (HUF 31 billion in total value) was qualified by the Hungarian Government as a major priority for the national economy. For this investment, the company won the 'Investors of the Year 2015' award in Hungary (in the green-field investment category). The factory was opened in 2017. In Túrkeve, SMR Hungary opened a new SMR plant in 2018 and a new MATE plant in 2019. These two investments of SMR Hungary amounted to HUF 8 billion. The Hungarian Government provided a HUF 0.624 billion and HUF 1.482 billion cash grant for these projects.

In addition, several other investments from China and India have targeted Hungary since the launch of the Eastern Opening policy in 2012. In the case of China, we have to highlight that the FDI attraction in Hungary's Eastern Opening policy is strongly interconnected with China's Belt and Road Initiative. Hungary was the first European country to officially sign an MoU on the Belt and Road Initiative with China in 2015. In 2016, on the sidelines of the fifth China-CEE Summit in Riga, Hungary and China signed an agreement to establish a state-owned joint venture company (Chinese-Hungarian Railway Non-profit Ltd.) responsible for coordinating the upgrade of the Hungarian section of the Budapest-Belgrade railway line, which is a flagship project under the BRI. In 2017, Hungarian telecom firm Invitel was acquired by the China-Central and Eastern Europe Investment Cooperation Fund which was established, among others, by the Export-Import Bank of China and the Hungarian Export-Import Bank. Chinese BYD invested HUF 6.2 billion in Hungary and it opened its first European electric bus factory in Komárom in 2017. The Hungarian Government provided a 0.925 billion cash grant to the company and HIPA provided comprehensive project management services to the company. In November 2018, Hungarian Prime Minister Viktor Orbán, accompanied by a business and official delegation, visited the China International Import Expo in Shanghai where the Hungarian Government signed a contract on the construction of a solar power plant with National Machinery Import \& Export Corporation $(C M C)$, which is a subsidiary of Chinese state-owned company Genertec. CMC started to build the largest photovoltaic power station of Central Europe in Kaposvár in June 2019. The project is designated by the Chinese state media as a new achievement of China's Belt and Road Initiative and Hungary's Eastern Opening policy (Wen 2019). 
In the case of India, it is worth highlighting four new green-field investors, all of which have received a certain amount of cash grant from the Hungarian Government. In 2014, Apollo Tyres selected Hungary out of eight CEE countries to establish its second factory in Europe. The Indian investor's decision was highly influenced, among others, by the friendly approach of the Hungarian Government and a EUR 55 million cash grant and tax incentives (Lokeshwarri 2017). At the opening ceremony of the factory in 2017, Hungarian Prime Minister Viktor Orbán said that Apollo Tyres' investment had arrived in Hungary due to the Eastern Opening policy (Cabinet Office of the Prime Minister 2017). Apollo Tyres won the 'Investors of the Year 2014' award for this investment (in the green-field investment category). In July 2016, during an official trip to India, Hungarian Minister of Foreign Affairs and Trade, Péter Szijjártó, related that 'Hungary's goal is for Indian enterprises that are successful on the European markets to bring their new investments here, and especially for Indian automobile industry companies that are successful on European markets to bring their production centres to Hungary' (Cabinet Office of the Prime Minister-Hungarian New Agency 2016). Regarding the achievement of this goal, he announced the investment of Indian Sona Group which had decided on opening a new European factory in Hungary. The new plant of Sona Group in Hungary was launched in 2017, when the further expansion of the plant, to be financed in part by a HUF 0.633 billion cash grant from the Hungarian Government, was announced. In 2018, Indian chemical company, SRF Group, started to build its first European plant in Jászfényszaru to produce BOPET foil. The investment amounted to EUR 56 million. The Hungarian Government provided a EUR 3.5 million cash grant to SRF Group. Hungary won the race for SRF's investment amid stiff international competition thanks to its attractive investment environment. Among other factors, the success of Indian companies already operating in Hungary contributed to $S R F$ 's choice of Hungary (Hungarian News Agency 2018a). At the end of 2018, another Indian chemical company, Uflex Group, announced that it would build its second European factory in Hungary to produce a completely new type of foil (HIPA 2018). There was considerable regional competition for the investment and a 3 year cooperation agreement between Invest India and HIPA, concluded on the side-lines of the 5th session of the Hungarian-Indian Joint Committee for Economic Cooperation held in New Delhi in March 2018, played an important role in winning over Uflex Group. The Hungarian Government awarded Uflex Group a EUR 8.7 million cash grant for the investment (EUR 71.5 million) (Hungarian News Agency 2018b). In January 2020, Hungarian Minister of Foreign Affairs and Trade, Péter Szijjártó, visited Mumbai where he successfully concluded agreements on investments in Hungary with Tata Sons, Mahindra and Hinduja Group (Hungarian News Agency 2020).

\section{Conclusions}

Besides providing a detailed and up-to-date analysis of sectoral distribution, modes of market entry and motivations of Chinese and Indian investments in Hungary, this paper investigates the influence of the Hungarian Government's Eastern Opening policy on these investments. Since 2000, Chinese and Indian foreign direct investments have started to increase in Hungary and more rapidly since 2010. In the case of China, both 
private and state-owned companies are present in Hungary. Indian foreign direct investments mainly originate from privately owned large business groups or standalone companies (mainly in the IT/BPO sector). Chinese and Indian companies enter the Hungarian economy mainly through green-field investments or acquisitions. Regarding the mode of market entry, it is worth highlighting the growing number of Chinese acquisitions in the automotive sector and Indian companies' preference for greenfield investments over acquisitions over the last decade. The sectoral distribution of Chinese and Indian investments has become more diversified since 2010. In addition, Chinese companies have especially preferred to invest in the automotive and renewable energy sectors. In the case of Indian companies, we can see a sectoral preference for the automotive and chemical industries over the last decade. We find that market-seeking and strategic asset-seeking motives are dominant in the case of investors from both countries. Market-seeking investments often do not target only the Hungarian domestic market but also the whole European market. Strategic assetseeking investors usually acquire foreign companies with Hungarian subsidiaries or companies with Hungarian roots.

We find evidence that the Eastern Opening policy launched in 2012 has had a significant impact on the rapid increase of Chinese and Indian investments. The investment decision (location choice) of new Chinese and Indian investors and further expansion of investments by Chinese and Indian companies located in Hungary have been positively influenced by the following four factors - high-ranking political meetings, strategic cooperation agreements, cash grants from the Hungarian Government and supportive services of HIPA.

Funding Open access funding provided by ELKH Centre for Economic and Regional Studies.

Open Access This article is licensed under a Creative Commons Attribution 4.0 International License, which permits use, sharing, adaptation, distribution and reproduction in any medium or format, as long as you give appropriate credit to the original author(s) and the source, provide a link to the Creative Commons licence, and indicate if changes were made. The images or other third party material in this article are included in the article's Creative Commons licence, unless indicated otherwise in a credit line to the material. If material is not included in the article's Creative Commons licence and your intended use is not permitted by statutory regulation or exceeds the permitted use, you will need to obtain permission directly from the copyright holder. To view a copy of this licence, visit http://creativecommons.org/licenses/by/4.0/.

\section{References}

Athukorala P (2009) Outward foreign direct investment from India. Asian Dev Rev 26(2):125-153

Athukorala P, Veeramani C (2016) Internationalization of Indian enterprises: patterns, determinants and policy issues. Working Papers in Trade and Development 4, March 2016. https://acde.crawford.anu.edu.au/sites/ default/files/publication/acde_crawford_anu_edu_au/2016-05/2016-04_athukorala_verramani_ internationalization_wp.pdf. Accessed 4 March 2019

Balcet G, Bruschieri S (2010) Acquisition of technologies and multinational enterprise growth in the automotive and the pharmaceutical industries: drivers and strategies. In: Sauvant KP, Pradhan JP, Chatterjee A, Harley B (eds) The rise of Indian multinationals: perspectives on Indian outward foreign direct investment. Palgrave Macmillan, New York, pp 111-165

Bana S (2015) Hungary-India links 'win-win'. The Budapest Times, 30 October 2015, https://budapesttimesarchiv.bzt.hu/2015/10/30/hungary-india-links-win-win/. Accessed 18 June 2020 
Cabinet Office of the Prime Minister (2017) Speech by Viktor Orbán at the inauguration ceremony for the new Apollo Tyres production plant. 7 April 2017, http:/www.miniszterelnok.hu/speech-by-viktor-orban-atthe-inauguration-ceremony-for-the-new-apollo-tyres-production-plant/. Accessed 17 June 2020

Cabinet Office of the Prime Minister, Hungarian New Agency (2016) Yet another Indian automobile industry investment in Hungary; Hungarian construction industry company to be established in India. 8 July 2016, https:/www.kormany.hu/en/ministry-of-foreign-affairs-and-trade/news/yet-another-indian-automobileindustry-investment-in-hungary-hungarian-construction-industry-company-to-be-established-in-india. Accessedd 17 June 2020

Chaudhry D, Tomar P, Joshi P (2018) deconstructing Indian overseas foreign direct investments: historical and contemporary trends. Oxfam Discussion Papers, March 2018. http://icrier.org/pdf/Deconstructing Indian Overseas FDI.pdf. Accessed 4 March 2019

Dániel P (2015) The eastern opening - an element of Hungary's trade policy. Final paper - EUP413 Europe in global economy. https://www.researchgate.net/publication/282217890_The_Eastern_Opening__An_ Element of Hungary\%27s Trade Policy. Accessed 5 March 2019

Dunning JH, Kim C, Park D (2008) Old wine in new bottles: a comparison of emerging-market TNCs today and developed-country TNCs thirty years ago. In: Sauvant KP (ed) The rise of transnational corporations from emerging markets: threat or opportunity? Edward Elgar, Cheltenham \& Northampton, pp 158-180

Éltető A, Völgyi K (2013) The development of Hungarian foreign trade with Asia. IWE Working Paper 200, April 2013. http://real.mtak.hu/6801/. Accessed 5 March 2019

Geröcs T (2018) Indian companies' technological investments in the EU with a special focus on central and Eastern Europe. IWE working paper 248, November 2018. http://real.mtak.hu/88093/1/WP 248_Ger\% C5\%91cs.pdf. Accessed 11 June 2020

Hansen MW (2010) In search of the "Indianness" of Indian multinational enterprises: is there anything special about the Indian path to outward foreign development. In: Sauvant KP, Pradhan JP, Chatterjee A, Harley B (eds) The Rise of Indian Multinationals: Perspectives on Indian Outward Foreign Direct Investment. Palgrave Macmillan, New York, pp 25-55

Hay F (2016) Chinese investors in Europe: some idiosyncrasies. In: Brennan L, Bakir C (eds) Emerging market multinationals in Europe. Routledge, London \& New York, pp 115-128

Hay F, Milelli C (2011) Chinese and Indian firms in Europe: Main characteristics and presumed impacts. In: Brennan L (ed) The emergence of southern multinationals: their impact on Europe. Palgrave Macmillan, pp 151-164

HIPA (2016) Yanfeng creates 450 new jobs in Pápa. 27 April 2016, https://hipa.hu/yanfeng-creates-450-newjobs-in-papa. Accessed 14 June 2020

HIPA (2017) Tata consultancy services and Hungary committing to the digital future. 18 April 2017, https:// hipa.hu/tata-consultancy-services-and-hungary-committing-to-the-digital-future. Accessed 14 June 2020

HIPA (2018) Uflex to strengthen its European position by a manufacturing base in Hungary. 21 November 2018, https://hipa.hu/uflex-to-strengthen-its-european-position-by-a-manufacturing-base-in-hungary. Accessed 10 March 2019

HIPA (2020): SEGA to enter into a strategic partnership with the government - video report. 21 February 2020, https:/hipa.hu/sega-to-enter-into-a-strategic-partnership-with-the-government. Accessed 20 June 2020

Hungarian News Agency (2018a) The eastern opening policy is bringing new investors to Hungary. 16 June 2018, https://www.kormany.hu/en/ministry-of-foreign-affairs-and-trade/news/the-eastern-openingpolicy-is-bringing-new-investors-to-hungary. Accessed 17 June 2020

Hungarian News Agency (2018b) New packaging material production plant to be established in Rétság with an investment of 23 billion forints. 21 November 2018, https:/www.kormany.hu/en/ministry-of-foreignaffairs-and-trade/news/new-packaging-material-production-plant-to-be-established-in-retsag-with-aninvestment-of-23-billion-forints. Accessed 17 June 2020

Hungarian News Agency (2020) Indian companies to create one thousand new jobs in Hungary. 15 January 2020, https:/www.kormany.hu/en/ministry-of-foreign-affairs-and-trade/news/indian-companies-tocreate-one-thousand-new-jobs-in-hungary. Accessed 17 June 2020

KPMG (2018) China Outlook 2018: A new era, a new paradigm of globalization. https://assets.kpmg/content/ dam/kpmg/cn/pdf/en/2018/03/china-outlook-2018.pdf. Accessed 4 March 2019

Leepsa N M, Mishra C S (2012) Crompton Greaves: a case study on what makes a merger successful. $2^{\text {nd }}$ International Conference on Management, 11-12 June 2012, Langkawi Kedah, Malaysia, https://www. researchgate.net/profile/Nm_Leepsa2/publication/267823719_CROMPTON_GREAVES_A_CASE STUDY_ON_WHAT_MAKES_A_MERGER_SUCCESSFŪL/links/5491488900f214269f $27 \mathrm{ebb} \overline{7 /}$ CROMPTON-GREAVES-A-CASE-STUDY-ON-WHAT-MAKES-A-MERGER-SUCCESSFUL.pdf? origin=publication_detailn. Accessed 11 March 2019 
Li Y (2018) China's go out policy: a review on China's promotion policy for outward foreign direct investment from a historical perspective. IWE working paper 244, September 2018. http://www.vki.hu/ news/news 1267.html accessed 11 march 2019

Lokeshwarri S K (2017) Hungary welcomed us with smile and sops. The Hindu business line, 12 April 2017, https://www.thehindubusinessline.com/companies/hungary-welcomed-us-with-smile-and-sops/ article9634508.ece\# accessed 17 June 2020

Lukács E, Völgyi K (2017) Indian multinationals as an emerging source of FDI in the central and eastern European countries - a Hungarian perspective. IMBusiness 2(1):29-52

Lukács E, Völgyi K (2018a) China-Hungary economic relations under OBOR. China-CEE Institute, working paper 37, 22 November 2018. https:/china-cee.eu/wp-content/uploads/2019/01/Work_paper-201837Eszter-Luk\%C3\%A1cs-Katalin-V\%C3\%B6lgyi.pdf accessed 11 June 2020

Lukács E, Völgyi K (2018b) Evolving interconnectedness between China’s OBOR initiative and Hungary's eastern opening policy in a bilateral political framework. In: Cebeci K, Silva JR, Budak T, Focacci A (eds) MIRDEC-10 ${ }^{\text {th }}$ Barcelona 2018 conference proceedings. MIRDEC Publishing, Istanbul, pp 181-192

Matura T (2017) Chinese investments in the EU and central and Eastern Europe. In: Moldicz CS (ed) China's attraction: the case of Central Europe. OBIC, Budapest business school, University of Applied Sciences, Budapest, pp 49-71

Matura T (2018) Hungary and China relations. In: Song W (ed) China's relations with central and Eastern Europe: from "old comrades" to new partners. Routledge, London \& New York, pp 137-153

Matura T (2019) China-CEE trade, investment and politics. Eur Asia Stud 71(3):388-407

Meng C, Zhihua L, Chunyang J (2018) Outward direct investment by Chinese enterprises: a survey (20052016). In: Ding X, Meng C (eds) From world factory to global investor: multi-perspective analysis on China's outward direct investment. Routledge, London \& New York, pp 9-22

Milelli C (2016) Indian firms in Europe: Main characteristics, competitive advantages and strategies. In: Brennan L, Bakir C (eds) Emerging market multinationals in Europe. Routledge, London \& New York, pp 157-169

NGM (2011) Külgazdasági Stratégia - Szakmai vitairat. http://www.pestmegye.hu/images/2014/agazati strategiak/Kulgazdasagi_Strategia_2011.pdf. Accessed 5 March 2019

Pradhan JP (2017) Indian outward FDI: a review of recent developments. Transl Corp 24(2):43-70

Szunomár Á, McCaleb A, Chen X (2018) Economic relations between China and central and Eastern Europe: trade and investment issues. In: Song W (ed) China's relations with central and Eastern Europe: from "old comrades" to new partners. Routledge, London \& New York, pp 48-65

Szunomár Á, Karindi L, Leonte A (2020) Economic relations: a sugar cane, or a sugar-coated stick? In: Karásková I, Bachulska A, Szunomár Á, Vladisavljev S (eds) Empty shell no more: China’s growing footprint in central and Eastern Europe. Association for International Affairs, Prague, pp 35-56

UNCTAD (2006) World Investment Report 2006. In: FDI from developing and transition economies: implications for development. United Nations, New York \& Geneva

Wang B, Gao K (2018) Outward direct investment: restricted, relaxed and regulated stages of development. In: Garnaut R, Song L, Fang C (eds) China's 40 years of reform and development, 1978-2018. ANU Press, Acton, pp 619-636

Wells LT (1983) Third world multinationals: the rise of foreign investment from developing countries. MIT Press, Cambridge

Wen H (2019) Hungary's largest PV power station starts construction. 24 June 2019, http://en.sasac.gov.cn/ 2019/06/24/c 2130.htm. Accessed 16 June 2020

Zhang F (2018) Chinese investment in central and eastern European countries: the analysis of EU factor. Centre for Economic and Regional Studies, Institute of World Economics: Budapest, Challenges 230, August 2018

Zuokui L (2013) New opportunities and challenges for China's Investment in Central and Eastern Europe. In: Matura T (ed) Asian Studies - 2013. Hungarian Institute of International Affairs, Budapest, pp 152-166

Publisher's note Springer Nature remains neutral with regard to jurisdictional claims in published maps and institutional affiliations. 